\title{
The relationship between consumption and production system and its implications for sustainable development of China
}

\author{
Jingru Liu*, Rusong Wang, Jianxin Yang, Yao Shi \\ State Key Laboratory of Urban and Regional Ecology, Research Center for Eco-Environmental Sciences, Chinese Academy of Sciences, P.0. Box 2871, Beijing 100085, China
}

\section{A R T I C L E I N F O}

\section{Article history:}

Received 10 June 2009

Received in revised form 1 January 2010

Accepted 4 February 2010

Available online 2 March 2010

\section{Keywords:}

Sustainable consumption and production

Household consumption

Carbon dioxide emission

Life cycle analysis

\begin{abstract}
A B S T R A C T
Rapidly developing economy in China makes great improvement in human life quality. At the mean while, it brings great pressures on environment which has drawn broadly attentions all over the world. The 'problems of consumption' comes both from consumers and producers. Hybrid life cycle analysis method and structural decomposition analysis model were used in this paper to explore the interaction of consumption and production and how technology development and household consumption contributed to $\mathrm{CO}_{2}$ emissions in the period of 1992-2002. The achievements of technology development in the last two decades reduced the emission intensity and technical coefficients which lowered the $\mathrm{CO}_{2}$ emissions. But the household consumption has offset this technological contribution and resulted in the growth of $\mathrm{CO}_{2}$ emission. Interaction analysis results showed that consumer's demand for energyintensive product was an important driving force of pollution production. Household consumption in China contributed a lot to the expansion of manufacturing activities in the last two decades. We concluded that sustainable development could not be achieved if policy makers continuously emphasize the control of polluting industries. The government should simultaneously emphasize technological development and consumer policies to curb these emissions and induce more environmental conscious production and consumption patterns.
\end{abstract}

(C) 2010 Elsevier B.V. All rights reserved.

\section{Introduction}

People kept exploring the applicable path for sustainable development for decades and social responses to environmental problems have focused largely on the production side of economic activities. But evidences have shown that over the last decade, changes in consumption patterns have offset the environmental achievements from industrial technological improvement (UNEP, 2002; Spangenberg and Lorek, 2002; Princen, 2003; Clark, 2007). During the UNCED conference in Rio de Janeiro 1992, unsustainable consumption patterns, together with unsustainable production patterns were identified as the key driving forces behind the unsustainable development of the world. This became the starting point for international work directed to improving understanding of global consumption patterns and their environmental impacts (Lintott, 1998; Farah and Allely, 2003; Nansai et al., 2007).

Households are the mainly final consumption sectors which consist of the most part of gross domestic product. The households' consumption behavior can impact the environment directly and indirectly. The indirect impacts are associated with the production processes of commodities and services for households (Noorman,

\footnotetext{
* Corresponding author. Tel.: +86 10 62849110; fax: +86 1062943807 .

E-mail address: liujingru@rcees.ac.cn (J. Liu).
}

1998). From a life cycle point of view, consumption behavior is not an isolated phase. The resources consumed as well as the pollution released from production process can be allocated to end-uses. Thus, the UNEP proposed a life cycle thinking when it brought forward the definition of sustainable consumption in 1994 (UNEP, 1994).

China is a rapid developing country with huge population. The human life quality in China has been great improved after taking the open-the-door policy. Along with income increase and living standard improvement, private consumption brings great pressures on the deteriorating environment which has drawn broadly attention all over the world (Liu and Diamond, 2005). The government is now facing a serious situation to balance the economy development and environmental protection. It is now widely accepted by managers that shifting from cleaner production practices to sustainable production and consumption economy activities is an indispensable path for achieving sustainable development in China (China's Agenda 21, 1994). It is essential to analyze the synergetic relations of production and consumption systemically to set out a course of action for sustainable development practices.

China is the second largest $\mathrm{CO}_{2}$ emitter in the world and households is an important contributor of GHG emissions (Lenzen, 1998; Munksgaard et al., 2002; Lenzen and Dey, 2002). In this research, we chosen $\mathrm{CO}_{2}$ emissions connected with energy consumption as an indicator to reflect the environmental impact 
Table 1

$\mathrm{CO}_{2}$ emission factors of energy fuels.

\begin{tabular}{|c|c|c|c|c|}
\hline Fuel & Emission factor $(\mathrm{Tc} / \mathrm{TJ})$ & Carbon oxidation rate (\%) & $\mathrm{NCV}\left(\mathrm{MJ} / \mathrm{t} \mathrm{m}^{3}, \mathrm{tce}\right)$ & Emission factor $\left(\mathrm{CO}_{2} / \mathrm{TJ}\right)$ \\
\hline Raw coal & 24.74 & 94.4 & 20908 & 90.65 \\
\hline Clean coal & 24.74 & 94.4 & 26344 & 90.65 \\
\hline Other washed coal & 24.74 & 94.4 & 8363 & 90.65 \\
\hline Coke & & 97 & 28435 & 74.02 \\
\hline Coke oven gas & 20.2 & 99 & 16726 & \\
\hline Other gas & 20.2 & 99 & 5227 & 74.02 \\
\hline Crude oil & 20 & 98 & 41816 & 73.28 \\
\hline Diesel & 20.2 & 98 & 42652 & 74.02 \\
\hline Fuel oil & 21.1 & 98 & 41816 & 77.31 \\
\hline LPG & 17.2 & 99 & 50179 & 63.02 \\
\hline Refinery gas & 20 & 99 & 46055 & 73.28 \\
\hline Natural Gas & 15.3 & 99 & 38931 & 56.06 \\
\hline Other petroleum products & 20.2 & 98 & 41816 & 74.02 \\
\hline Other coking products & 25.8 & 97 & 28435 & 94.54 \\
\hline
\end{tabular}

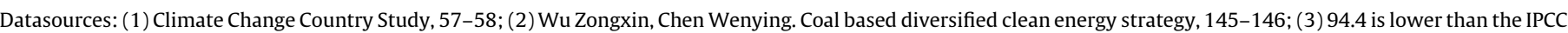
default value, which is the estimation of industrial average value in China.

of household consumption. Using the hybrid life cycle analysis method and related mathematic models, we established an environmental extended input-output table of China by combing with energy statistic data and calculated the carbon dioxide $\left(\mathrm{CO}_{2}\right)$ emission intensities of production sectors in 1992, 1997 and 2002. Structural decomposition analysis was then used to calculate the contribution of technology development and lifestyle changes to the total consumption-related $\mathrm{CO}_{2}$ emission changes from 1992 to 1997 and 1997 to 2002. The relationship of $\mathrm{CO}_{2}$ emissions between consumption and production system was analyzed. The key points for Chinese sustainable consumption and production development were identified and discussed.

\section{Methods, data sources and models}

\subsection{Hybrid life cycle analysis}

There are two basic methods in compiling life cycle inventory: process analysis and input-output analysis (Suh et al., 2004). Process analysis is a bottom-up technique and input-output analysis is a top-down macroeconomic technique that uses sectoral monetary transactions matrix to describe the structure of an economy in terms of interactions among industries and between them and households (Lenzen, 2002). One of the most important applications of inputoutput analysis is to calculate the total input requirements for a unit of final demand. By doing this, one can assess not only the direct requirement in the production process of the analyzed sector itself, but also all indirect requirements resulting from intermediated product deliveries from other sectors (Hubacek and Giljum, 2003). Consumption is related with products, by using hybrid LCA, it is easy to analyze the interactions between consumption and production. Since the input-output analysis is based on publicly available data, the method is less time consuming than process analysis (Munksgaard et al., 2005).

\subsection{Data sources and treatment of data}

By combing the Chinese input-output table, energy statistical book and $\mathrm{CO}_{2}$ emission factors, we calculated the $\mathrm{CO}_{2}$ emission intensity of industrial sectors. The Chinese input-output table was published each five years in 1992, 1997 and 2002. There are 118 industrial sectors in 1992s input-output table, 124 sectors in 1997s table and 122 sectors in 2002s table. To make a consistent analysis, we aggregated the number of industrial sectors to 97 according to the Chinese National Standard.

Eighteen kinds of energy fuels used by 40 industrial sectors are compiled in the Chinese energy statistic books. These 40 sectors' energy consumption and related $\mathrm{CO}_{2}$ emissions were disaggregated to 97 industrial sectors in input-output tables. The economic input-output table was linked with energy matrices based on some basic assumptions. The method of desegregation in this process is very important. More detailed methods are described in other references (Vringer and Blok, 1995; Lenzen et al., 2003; Sangwon, 2006; Hoekstra and Bergh, 2006). Allocations among sectors were based on the percentage of sector's price output to the total outputs of same group sectors.

The amount of $\mathrm{CO}_{2}$ emission is determined by types of fuel, discharge coefficient of carbon and oxidation rate (Table 1). To avoid double counting, we only considered the primary fuels for constructing emissions data. For example, the emission of coal was calculated, but the secondary energy of coal, like electricity, was out of our consideration. During the calculation, energy loss should be considered. The amount of total energy losses was achieved in China energy statistics yearbooks. We divided the total energy losses into each sector according to the amount of total energy used by that sector. The indirect $\mathrm{CO}_{2}$ emissions of household consumption are calculated by multiplying the sectoral cumulative $\mathrm{CO}_{2}$ intensities with household expenditures.

\subsection{Models}

\subsubsection{The basic input-output model}

The basic concepts of input-output analysis were developed by Leontief in the last 60th. Expanded models with environmental multipliers have been widely used and discussed since then (Chapman, 1974; Gay and Proops, 1993; Duchin, 1992; Lenzen, 1998; Hertwich, 2005). The basic equation of input-output analysis is:

$x=A_{x}+y \quad$ or $\quad x=(I-A)^{-1}$

where $x$ is the elements of a matrix $(n \times n)$ of intermediated demand of industries $j=1, \ldots, n$ from industries $i=1, \ldots, n . y$ is the $\operatorname{vector}(n \times 1)$ of final demand from industrial sectors. Each column $A_{j}$ is the requirements for one unit of output of sector. $(I-A)^{-1}$ is the key of input-output analysis, which is called Leontief inverse matrix.

\subsubsection{Expand input-output model with $\mathrm{CO}_{2}$ emission multiplier}

Assuming the total $\mathrm{CO}_{2}$ emission of industrial sector is $T_{i}$, the ratio of $T_{i}$ to $X_{i}$ can be defined as the direct $\mathrm{CO}_{2}$ emission coefficient of sector $i$ :

$w_{i}=\frac{T_{i}}{X_{i}}$ 
Table 2

Household expenditure and its $\mathrm{CO}_{2}$ emission pattern in 1992.

\begin{tabular}{|c|c|c|}
\hline & $\begin{array}{l}\text { Expenditure of } \\
\text { households } \\
\text { (ten thousand } \\
\text { RMB Yuan) }\end{array}$ & $\begin{array}{l}\mathrm{CO}_{2} \text { emission } \\
\text { (Ton) }\end{array}$ \\
\hline $\begin{array}{l}\text { Electricity, steam and hot water } \\
\text { production and supply }\end{array}$ & 573911 & 39840402 \\
\hline Other food products & 3896480 & 12082807 \\
\hline Gas production and supply & 348342 & 11050899 \\
\hline Health services & 3090651 & 6701261 \\
\hline Grain mill products & 3574215 & 6193993 \\
\hline Chemical products for daily use & 742268 & 5384558 \\
\hline Livestock and livestock products & 5963073 & 4774211 \\
\hline Wines, spirits and liquors & 1352941 & 3919784 \\
\hline Other agricultural products & 4769515 & 3818613 \\
\hline Pottery, china and earthenware & 168237 & 3505479 \\
\hline Highway passenger transport & 875985 & 3061655 \\
\hline Non-alcoholic beverage & 835363 & 2420240 \\
\hline $\begin{array}{l}\text { Slaughtering, meat processing, eggs } \\
\text { and dairy products }\end{array}$ & 1169935 & 2027458 \\
\hline Wholesale and retail trade & 4558410 & 1994890 \\
\hline $\begin{array}{l}\text { Culture and arts, radio, film } \\
\text { and television }\end{array}$ & 783969 & 1699830 \\
\hline Cotton textile & 865103 & 1561620 \\
\hline Fishery & 1895157 & 1517318 \\
\hline Education services & 688379 & 1492568 \\
\hline Residential services & 1826097 & 1451454 \\
\hline Storage and warehousing & 408871 & 1429045 \\
\hline Total of top 20 sectors & 38386902 & 115928086 \\
\hline Total in 1992 & 58885729 & 140199284 \\
\hline $\begin{array}{l}\text { Percentage of top } 20 \text { sectors to } \\
\text { total in } 1992\end{array}$ & $65.19 \%$ & $82.69 \%$ \\
\hline
\end{tabular}

Then the complete emission coefficient of sector $i$ can be calculate by Eq. (3):

$C=w+w A+w A^{2}+w A^{3}+\cdots=w(I-A)^{-1}$

where $C$ is the complete emission coefficient.

By combing the household consumption multiplier $y$, we can get:

$T W=w(I-A)^{-1} y=C y=\sum_{i=1}^{n} C_{i} \times y_{i}$

where $T W$ is total $\mathrm{CO}_{2}$ emission of household consumption. Eq. (4) can be used to track inputs and outputs along the full supply chain by identifying and quantifying both direct and indirect inputs to the final products under analysis. This makes the hybrid LCA a useful tool to investigate the linkage between consumption, production and environmental effects.

\subsubsection{Structural decomposition model}

Structural decomposition analysis (SDA) used in hybrid LCA has illustrated the power of this framework to address the relations between technology, lifestyle and the environment (Duchin, 1998). The $\mathrm{CO}_{2}$ emission different between time $t$ and time $t+1$ is caused by three factors:

$$
\begin{gathered}
T W(t)-T W(t-1)=\Delta w(I-A)^{-1}(t) y(t)+w(t-1) \Delta(I-A)^{-1} y(t) \\
\quad+w(t-1)(I-A)^{-1}(t-1) \Delta y
\end{gathered}
$$

where $\Delta w, \Delta(I-A)^{-1}$ and $\Delta y$ reflect the contribution of emission intensity, technology development and consumption behaviors to the total changes of $\mathrm{CO}_{2}$ emissions between time $t$ and time $t+1$. This mathematical model can be used to explore the key contributor of environmental impacts and identify opportunities for reducing environmental impacts.
Table 3

\begin{tabular}{|c|c|c|}
\hline & $\begin{array}{l}\text { Expenditure of } \\
\text { households } \\
\text { (ten thousand } \\
\text { RMB Yuan) }\end{array}$ & $\begin{array}{l}\mathrm{CO}_{2} \text { emission } \\
\text { (Ton) }\end{array}$ \\
\hline Electricity production and supply & 2486506.1 & 61924810 \\
\hline $\begin{array}{l}\text { Bricks, tiles, lime and light-weight } \\
\text { building materials }\end{array}$ & 2254239.5 & 13503005 \\
\hline Gas production and supply & 782239.6 & 11894629 \\
\hline $\begin{array}{l}\text { Grain mill products, vegetable oil } \\
\text { and forage }\end{array}$ & 9352178.3 & 5838455 \\
\hline Other food products & 10855131.5 & 5744349 \\
\hline Livestock and livestock products & 17685110.5 & 5660173 \\
\hline Telecommunication & 2162589.4 & 5357378 \\
\hline Chemical products for daily use & 1855719.2 & 4152877 \\
\hline Crop cultivation & 10486508.5 & 3361048 \\
\hline $\begin{array}{l}\text { Steam and hot water production } \\
\text { and supply }\end{array}$ & 122433.4 & 3054144 \\
\hline Pottery, china and earthenware & 457287.8 & 2737684 \\
\hline Wines, spirits and liquors & 4414956.7 & 2705351 \\
\hline Wholesale and retail trade & 11153463.6 & 2425659 \\
\hline $\begin{array}{l}\text { Slaughtering, meat processing, eggs } \\
\text { and dairy products }\end{array}$ & 3760775.0 & 2346038 \\
\hline Cement and asbestos products & 388366.4 & 2323116 \\
\hline Glass and glass products & 362640.4 & 2169911 \\
\hline Health services & 7389074.0 & 2109602 \\
\hline Cement & 346438.4 & 2072574 \\
\hline Fishery & 5601723.2 & 1794287 \\
\hline Non-alcoholic beverage & 2561443.0 & 1569673 \\
\hline Total of top 20 sectors & 94478824.6 & 142744763 \\
\hline Total in 1997 & 179806593.9 & 168968965 \\
\hline $\begin{array}{l}\text { Percentage of top } 20 \text { sectors to } \\
\text { total in } 1997\end{array}$ & $52.54 \%$ & $84.48 \%$ \\
\hline
\end{tabular}

Household expenditure and its $\mathrm{CO}_{2}$ emission pattern in 1997.

\section{Results}

\subsection{Relationship of consumption and production}

Using Eq. (4), we calculated the $\mathrm{CO}_{2}$ emissions patterns of Chinese household consumption in 1992, 1997 and 2002, respectively. The top 20 sectors which affect most in household

Table 4

Household expenditure and its $\mathrm{CO}_{2}$ emission pattern in 2002.

\begin{tabular}{lll}
\hline & $\begin{array}{l}\text { Expenditure of } \\
\text { households } \\
\text { (ten thousand } \\
\text { RMB Yuan) }\end{array}$ & $\begin{array}{l}\mathrm{CO}_{2} \text { emission } \\
(\text { Ton })\end{array}$ \\
& 9203126 & 153723643 \\
\hline $\begin{array}{l}\text { Electricity, steam and hot water } \\
\text { production and supply }\end{array}$ & 2783595 & 24234796 \\
Cement, lime and plaster & 1566024 & 10753325 \\
Gas production and supply & 7988056 & 8557116 \\
Telecommunication service & 26468219 & 8426237 \\
Animal husbandry & 19828897 & 6312589 \\
Agriculture & 695818 & 6057996 \\
Glass and glass products & 17895326 & 5456194 \\
All other food manufacturing & 21994855 & 5201730 \\
Educational services & 17580403 & 4157723 \\
Residential and other personal service & 2543219 & 4022053 \\
Chemical products for daily use & 442751 & 3854720 \\
Pottery, china and earthenware & 16025274 & 3789939 \\
Health & 3391052 & 3632626 \\
Urban public transport service & & \\
$\quad$ of passengers & 375481 & 3269048 \\
Other non-metallic mineral products & 25546781 & 3197336 \\
Food serving services & 23338895 & 2921006 \\
Real estate & 8807141 & 2803780 \\
Fishery & 2615136 & 2801435 \\
Water transport & 21811525 & 2729846 \\
Wholesale and retail trade services & 230901574 & 265903139 \\
Total of top 20 sectors & 362695996 & 305518631 \\
Total in 2002 & $63.66 \%$ & $87.03 \%$ \\
Percentage of top 20 sectors to & & \\
total in 2002 & & \\
\hline & & \\
\hline
\end{tabular}


Table 5

Expenditure and $\mathrm{CO}_{2}$ emission patterns of households in 1992, 1997 and 2002.

\begin{tabular}{|c|c|c|c|c|c|c|}
\hline \multirow[t]{2}{*}{ Year } & \multicolumn{2}{|c|}{ The first industry } & \multicolumn{2}{|c|}{ The second industry } & \multicolumn{2}{|c|}{ The third industry } \\
\hline & $\begin{array}{l}\text { Percentage of } \\
\text { expenditure }\end{array}$ & $\begin{array}{l}\text { Percentage of } \mathrm{CO}_{2} \\
\text { emission }\end{array}$ & $\begin{array}{l}\text { Percentage of } \\
\text { expenditure }\end{array}$ & $\begin{array}{l}\text { Percentage of } \mathrm{CO}_{2} \\
\text { emission }\end{array}$ & $\begin{array}{l}\text { Percentage of } \\
\text { expenditure }\end{array}$ & $\begin{array}{l}\text { Percentage of } \\
\mathrm{CO}_{2} \text { emission }\end{array}$ \\
\hline 1992 & 43.04 & 19.14 & 27.37 & 68.11 & 29.58 & 12.74 \\
\hline 1997 & 35.75 & 7.58 & 42.34 & 85.49 & 21.92 & 6.93 \\
\hline 2002 & 23.86 & 6.59 & 20.33 & 83.62 & 54.69 & 8.27 \\
\hline
\end{tabular}

Table 6

Structural decomposition analysis of changes in household $\mathrm{CO}_{2}$ emissions (unit: $\mathrm{tCO}_{2}$ ).

\begin{tabular}{|c|c|c|c|c|}
\hline Time period & Emission intensity & Technical coefficients & Household consumption & Sum \\
\hline 1992-1997 & $-3.64 \mathrm{E}+08$ & $-7.56 \mathrm{E}+07$ & $1.08 \mathrm{E}+09$ & $6.38 \mathrm{E}+08$ \\
\hline 1997-2002 & $-5.52 \mathrm{E}+08$ & $-2.38 \mathrm{E}+07$ & $6.21 \mathrm{E}+08$ & $4.53 E+07$ \\
\hline 1992-2002 & $-9.16 \mathrm{E}+08$ & $-9.94 \mathrm{E}+07$ & $1.70 \mathrm{E}+09$ & $6.84 \mathrm{E}+08$ \\
\hline
\end{tabular}

$\mathrm{CO}_{2}$ emissions are listed in Tables 2-4. It was shown that in 1992, $82.69 \%$ of household $\mathrm{CO}_{2}$ emission came from the top 20 sectors and about $65.19 \%$ of total household expenditure was used in these sectors. In $1997,84.48 \%$ of total $\mathrm{CO}_{2}$ emission was caused by the top 20 sectors, and $52.54 \%$ of total expenditure was used in these sectors (Table 3). In 2002, the $\mathrm{CO}_{2}$ emission amount of those 20 sectors accounted for $87.03 \%$ of total emission, and their expenditure was $63.66 \%$ of total expenditure (Table 4 ).

According to the industry classification standard of China, all sectors are classified into three industries categories, which are defined as the first, the second and the third industry, respectively. The first industry includes agriculture, forest, farming, and fishing. The second industry includes mining, manufacturing, electric power production, gas and water production, architecture and so on. The third industry includes all sectors which mainly include service sectors. The second industry is the most environmentally polluted industry and the third industry is considered as the most environmental friendly industry.

Based on this classification standard, we rearranged the sectors as shown in appendix 1 to appendix 3 and the results were summarized in Table 5. It was shown that for Chinese household consumption, the percentage of $\mathrm{CO}_{2}$ emission caused by the first industry was reducing gradually, and so did the expenditure on this industry. The expenditure on the third industry was increasing rapidly from $29.58 \%$ in 1992 to $54.69 \%$ in 2002, but the accordingly $\mathrm{CO}_{2}$ emission decreased. The contribution of the second industry to household $\mathrm{CO}_{2}$ emission reaches a peak to $85.49 \%$ in 1997 . This was consistent with the rapidly saturation of electric equipments in the middle of 1990s. In 2002, the contribution of the second industry still accounted for more than $80 \%$ of the total household $\mathrm{CO}_{2}$ emission, yet the expenditure on it was only half of 1997 , indicating that household had shifted their consumption to more pollution intensively products, such as private car and house.

\subsection{Technology, environment and lifestyle changes from 1992 to 2002}

The environmental impacts of households were decomposed into three determinants: the level of consumption, the composition of consumption and the environmental intensity of the goods and services produced for consumption (Ropke, 2001). The first two factors are related with consumption behavior and the third factor is decided by technology development. Eq. (5) was used to analyze the changes of households $\mathrm{CO}_{2}$ emission and the contribution of technology development and consumption behavior from 1992 to 2002. The structural decomposition analysis results are shown in Table 6 . Changes in emission intensity and technical coefficients reduced the $\mathrm{CO}_{2}$ emissions, this shows the achievement of technology development and we can conclude that the Chinese industry is now moving towards a less-polluting structure. But the household consumption has offset this technological contribution, resulting in the growth of $\mathrm{CO}_{2}$ emission. This reflects the limitation of technology development to the society sustainable development.

\section{Conclusions and implications for Chinese sustainable development}

In the last two decades, the resulting gains in Chinese people's living standards have been impressive, but the environmental cost is also very huge. There is growing recognition that multiple actors are interacting with diverse rules across complex decision-making arenas (Saravanan, 2008). Structural component analysis method was used in this paper, the results showed that in the last two decades, the increasing consumption $\mathrm{CO}_{2}$ emission had offset the achievements taken by technology development. Households are becoming a more and more important contributor for the generation of $\mathrm{CO}_{2}$ due to the indirect impact of their demand for products and services. Interaction analysis results showed that consumer's demand for energy-intensive product was an important driving force of pollution production. In the last two decades, household consumption has significant contribution to the expansion of manufacturing activities in China.

The government should simultaneously emphasize technological development and consumer policies to reduce these emissions and induce more environmental conscious production and consumption patterns (Kim, 2002). Pollution control measures and actions of Chinese government have focused largely on the production side of economic activities: innovative technologies for material mining, energy supply and manufacturing. But the China's rapid increase in household number and reduction in household size also have had significant environmental consequences (Liu and Diamond, 2005). It is important for China to put forward sustainable consumption and ensure sustainable development.

The Chinese government is now actively seeking policies to promote sustainable consumption. However, fundamental research on sustainable consumption obviously lags behind the demand of enacting policies. In 1994, the Chinese government published its Agenda 21, in which the Chapter 7 was devoted to issues concerning sustainable consumption (China's Agenda 21, 1994). This was followed up by a lot of practical activities organized by the government and the NGOs (CI and UNEP, 2004). The government plays an important role in promotion organic food, ISO 14000 certification and eco-labeling. Compared with developed countries, China still needs to do a lot of work to promote sustainable 
consumption and production patterns. It is imperative for China to clearly understand its consumption patterns and its mechanisms and to take activities to promote sustainable patterns of production and consumption. If policy makers continuously emphasize the control of polluting industries and products, it may be difficult to achieve a satisfactory environmental performance. If proper measures were taken, the consumer will becoming an influential force through their demand side pushing production to be more environmental friendly pattern.

\section{Acknowledgements}

This research was supported by the Chinese National Scientific Foundation (No. 70873122) and National Basic Research Program of China (No. 2005CB724206). We gratefully acknowledge the discussions with and the support of Edgar Hertwich and Peters Glen from Norwegian University of Science and Technology.

\section{References}

Chapman, P.F., 1974. Energy costs: a review of methods. Energy Policy 2 (2), 91-103. Chinese Environmental Sciences Press, Beijing.

Consumers International, UNEP, 2004. Tracking Progress: Implementing Sustainable Consumption Policies. CI \& UNEP, Kenya.

Clark, G., 2007. Evolution of the global sustainable consumption and production policy and the United Nations Environment Programme's supporting activities. Journal of Cleaner Production 15, 429-498.

Duchin, F., 1992. Industrial input-output analysis: implications for industrial ecology. Proceedings of the National Academy of Sciences 89, 851-855.

Duchin, F., 1998. Structural Economics-Measuring Changes in Technology, Lifestyles, and the Environment. Island Press, Washington, DC.

Farah, A.Z., Allely, E.G., 2003. Household consumption patterns in OECD countries: trends and figures. Journal of Cleaner Production 11, 819-827.

Gay, P.W., Proops, J.L.R., 1993. Carbon-dioxide production by the UK economy: an input-output assessment. Applied Energy 44, 113-130.

Hertwich, E.G., 2005. Life cycle approaches to sustainable consumption: a critical review. Environmental Science and Technology 39, 4672-4684.

Hoekstra, R., Bergh, J.G.J.M., 2006. Constructing physical input-output tables for environmental modelling and accounting: framework and illustrations. Ecological Economics 59, 375-393.

Hubacek, K., Giljum, S., 2003. Applying physical input-output analysis to estimate land appropriation of international trade activities. Ecological Economics 44, 137-151.
Kim, J.H., 2002. Changes in consumption patterns and environmental degradation in Korea. Structural Changes and Economic Dynamics 13, 1-48.

Lenzen, M., 1998. Energy and greenhouse gas cost of living for Australia during 1993/94. Energy 23, 497-516.

Lenzen, M., 2002. A guide for compiling inventories in hybrid life-cycle assessments: some Australian results. Journal of Cleaner Production 10, 545-572.

Lenzen, M., Dey, C.J., 2002. Economic, energy and greenhouse emissions impacts of some consumer choice, technology and government outlay options. Energy Economics 24, 377-403.

Lenzen, M., Murray, S.A., Korte, B., Dey, C.J., 2003. Environmental impact assessment including indirect effects-a case study using input-output analysis. Environmental Impact Assessment Review 23, 263-282.

Lintott, J., 1998. Beyond the economics of more: the place of consumption in ecological economics. Ecological Economics 25, 239-248.

Liu, J.G., Diamond, J., 2005. China's environment in a globalizing world: how china and the rest of the world affect each other. Nature 435 (30),1179-1186.

Munksgaard, J., Pedersen, K.A., Wien, M., 2002. Impact of household consumption on $\mathrm{CO}_{2}$ emissions. Energy Economics 22, 423-440.

Munksgaard, J., Wier, M., Lenzen, M., Dey, C., 2005. Using input-output analysis to measure the environmental pressure of consumption at different spatial levels. Journal of Industrial Ecology 9, 169-185.

Nansai, K., Kagawa, S., Moriguchi, Y., 2007. Proposal of a simple indicator for sustainable consumption: classifying goods and services into three types focusing on their optimal consumption levels. Journal of Cleaner Production $15,879-885$.

Noorman, K.J., 1998. Green households? Domestic, consumers, environment and Sustainability. Earthscan Publications Ltd., London.

Princen, T., 2003. Principles for sustainability: from cooperation and efficiency to sufficiency. Global Environmental Politics 3, 33-50.

Ropke, I., 2001. The environmental impact of changing consumption patterns: a survey. International Journal of Environment and Pollution 15, 127-145.

Sangwon, S., 2006. Handbook on Input-Output Economics in Industrial Ecology. Springer, Netherlands.

Saravanan, V.S., 2008. A systems approach to unravel complex water management institutions. Ecological Complexity 5, 202-215.

Spangenberg, J.H., Lorek, S., 2002. Environmentally sustainable household consumption: from aggregate environmental pressures to priority fields of action. Ecological Economics 43, 127-140

Suh, S., Lenzen, M., Treloar, G.J., Hondo, H., Horvath, A., Huppens, G., Jolliet, O., Klann, U., Krewitt, W., Moriguchi, Y., Munksgaard, J., Norris, G., 2004. System boundary selection in life-cycle inventories using hybrid approaches. Environmental Science and Technology 38, 657-664.

United Nations Environment Programme, 1994. Elements for policies for sustainable consumption. In: Symposium: Sustainable Production and Consumption Pattern, Oslo.

United Nations Environment Programme, 2002. Sustainable Consumption-A Global Status Report. UNEP, Paris.

Vringer, K., Blok, K., 1995. The direct and indirect energy requirements of households in the Netherlands. Energy Policy 23, 893-910. 